\title{
PERBANDINGAN TARIF JASA RAWAT INAP MENGGUNAKAN METODE TRADITIONAL COSTING DAN ACTIVITY BASED COSTING
}

\author{
Meliza Putriyanti Zifi' ${ }^{1}$, Zainal Arifin Renaldo ${ }^{2}$, Raihania Salsabila ${ }^{3}$ \\ Politeknik Caltex Riau \\ meliza@pcr.ac.id
}

\begin{abstract}
This study aims to find out how to implement the activity based costing method as the basis for determining the rates of inpatient services at Jambi Hospital. In conducting this research, the method used by the writer is quantitative descriptive method. Based on the results of the study, the tariff setting uses the activity based costing method to produce cheaper rates for VIP, Class I, and Class II, while generating more expensive rates for Class III compared to the rates set by Jambi Hospital. Rates for inpatient services with an activity based costing method for VIP Rp 670.435, Class I Rp 431.491, Class II Rp 373.275, and Class III Rp 331.508 .
\end{abstract}

Keywords: Activity Based Costing; Traditional Costing; Inpatient Service Tariff

\begin{abstract}
Abstrak
Penelitian ini bertujuan untuk mengetahui bagaimana menerapkan metode penetapan biaya berdasarkan aktivitas sebagai dasar untuk menentukan tingkat layanan rawat inap di Rumah Sakit XXX Jambi. Dalam melakukan penelitian ini, metode yang digunakan oleh penulis adalah metode deskriptif kuantitatif. Berdasarkan hasil penelitian, penetapan tarif menggunakan metode penetapan biaya berdasarkan aktivitas untuk menghasilkan tarif yang lebih murah untuk VIP, Kelas I, dan Kelas II, sementara menghasilkan tarif yang lebih mahal untuk Kelas III dibandingkan dengan tarif yang ditetapkan oleh Rumah Sakit XXX Jambi. Tarif untuk layanan rawat inap dengan metode penetapan biaya berdasarkan aktivitas untuk VIP Rp 670.435, Kelas I Rp 431.491, Kelas II Rp 373.275, dan Kelas III Rp 331.508.
\end{abstract}

Kata Kunci : Biaya Berdasarkan Aktivitas; Biaya Tradisional; Tarif Rawat Inap

* Corresponding author's e-mail: meliza@pcr.ac.id

http://openjournal.unpam.ac.id/index.php/JABI 
Jurnal Akuntansi Berkelanjutan Indonesia - Vol. 3, No. 2, Mei 2020 - Zifi; Renaldo \& Salsabilah

\section{PENDAHULUAN}

Dalam memberikan layanan kesehatan, rumah sakit menerima pendapatan dari pendapatan layanan dan fasilitas yang telah disediakan. Salah satunya adalah layanan rawat inap. Di mana pendapatan dari layanan dapat diperoleh dari tarif yang harus dibayar oleh pengguna layanan rawat inap. Menurut Aini \& Dwi (2012), menentukan tarif untuk layanan rawat inap adalah keputusan yang sangat penting karena dapat mempengaruhi profitabilitas rumah sakit. Dengan berbagai fasilitas dalam layanan rawat inap, serta jumlah biaya overhead yang tinggi, semakin menuntut akurasi dalam penetapan biaya yang sebenarnya. Jika perhitungan harga pokok barang kurang akurat dalam perhitungannya, yang akan terjadi adalah munculnya tarif yang terlalu rendah atau tarif yang terlalu tinggi. Tarif yang terlalu rendah atau terlalu tinggi juga tidak baik untuk rumah sakit. Tarif yang terlalu rendah tidak dapat mencakup semua biaya yang dikeluarkan oleh rumah sakit dan rumah sakit yang berorientasi laba tidak mendapatkan manfaat yang diharapkan dan jika situasi ini terus berlanjut akan menyebabkan kebangkrutan. Sebaliknya, tarif yang terlalu tinggi juga tidak baik karena rumah sakit akan kesulitan bersaing dengan pesaingnya.

Perhitungan harga biaya awalnya diterapkan di perusahaan manufaktur, tetapi dalam perkembangannya perhitungan harga biaya telah diadaptasi oleh perusahaan jasa, perusahaan perdagangan, dan sektor nirlaba. Dalam pasal 3 Keputusan Menteri Kesehatan No. 560/MENKES/SK/IV/2003 tentang pola tarif per jam rumah sakit dihitung berdasarkan biaya unit dari setiap jenis kelas layanan dan perawatan, yang perhitungannya menunjukkan ekonomi kapasitas masyarakat, standar biaya dan pembandingan komersial yang buruk. Fakta ini menunjukkan bahwa pemerintah telah menyadari pentingnya menghitung harga dasar termasuk di sektor layanan kesehatan (Pelo, 2012). Selama ini rumah sakit dalam menghitung tarif kamar rawat inap berdasarkan biaya tradisional. Biaya tradisional dalam menentukan penentuan biaya dasar mana yang tidak lagi mencerminkan kegiatan spesifik karena banyak kategori biaya tidak langsung dan cenderung diperbaiki. Menurut Maghfira \& Basri (2016), penetapan tarif untuk layanan rawat inap di banyak rumah sakit masih menggunakan metode akuntansi biaya tradisional yang hanya menggunakan pendorong aktivitas tingkat unit untuk membebankan biaya, menyebabkan masalah, karena produk yang dihasilkan tidak mencerminkan keseluruhan biaya yang diserap.

Ketepatan dalam menentukan biaya produk atau layanan diperlukan oleh semua perusahaan sehingga tidak ada kesalahan dalam pengambilan keputusan, kontrol, dan perencanaan diungkapkan oleh Nailufar et al (2015). Activity Based Costing yang merupakan sistem informasi akuntansi yang mengidentifikasi berbagai kegiatan yang dilakukan dalam suatu organisasi dan mengumpulkan biaya berdasarkan karakteristik aktivitas yang ada. Menurut Fadilah (2009), Activity Based Costing adalah pendekatan untuk menentukan biaya suatu produk atau jasa berdasarkan konsumsi sumber daya yang disebabkan oleh aktivitas.

* Corresponding author's e-mail: meliza @ pcr.ac.id

http://openjournal.unpam.ac.id/index.php/JABI 
Jurnal Akuntansi Berkelanjutan Indonesia - Vol. 3, No. 2, Mei 2020 - Zifi; Renaldo \& Salsabilah

Penelitian sebelumnya (Rikardo, 2016) tentang perbandingan penetapan tarif rawat inap Rumah Sakit Sumoharjo dengan menggunakan Activity Based Costing dengan metode tradisional menyimpulkan bahwa perhitungan tarif rawat inap menggunakan Activity Based Costing memberikan hasil yang lebih kecil untuk kelas I dan tarif yang lebih besar untuk kelas II, III, dan VIP.

Rumah Sakit Jambi (RS Jambi) adalah objek yang dijadikan fokus penelitian. RS Jambi menawarkan berbagai jenis layanan yaitu layanan rawat jalan dan layanan rawat inap. XXX Rumah Sakit Jambi didirikan pada 2012 dan termasuk rumah sakit tipe C. Layanan rawat inap memiliki beberapa jenis kamar, yaitu 4 kamar untuk VIP, 6 kamar untuk Kelas I, 9 kamar untuk Kelas II, 12 kamar untuk Kelas III. Rumah Sakit menerapkan tarif untuk layanan rawat inap berdasarkan penetapan biaya tradisional, yaitu menjumlahkan biaya tetap, biaya variabel, dan biaya semi-variabel kemudian total biaya tersebut dibagi dengan jumlah hari rawat inap. Hal ini menyebabkan distorsi dalam penentuan tarif. Rumusan masalah dalam penelitian ini adalah bagaimana perbandingan perhitungan tarif layanan rawat inap metode traditional costing dan activity based costing pada RS Jambi. Sedangkan tujuan penelitian ini adalah untuk mengetahui perbandingan perhitungan tarif layanan rawat inap metode traditional costing dan activity based costing pada RS Jambi. Kontribusi penelitian ini adalah pihak RS Jambi mengetahui perbandingan perhitungan tarif layanan rawat inap dengan menggunakan metode traditional costing dan activity based costing dan dapat dijadikan evaluasi dalam menentukan tarif layanan rawat inap.

\section{KERANGKA TEORITIS DAN PENGEMBANGAN HIPOTESIS}

Menurut Hansen \& Mowen (2012), menyatakan Activity-Based Costing Method adalah sistem perhitungan biaya yang pertama-tama melacak biaya ke aktivitas dan kemudian ke produk. Activity Based Costing menghitung biaya produk dan membebankan biaya produk sesuai dengan objek biaya berdasarkan aktivitas yang diperlukan untuk menghasilkan barang dan jasa. Metode Activity Based Costing akan menghasilkan perhitungan yang lebih akurat, karena metode ini dapat secara akurat mengidentifikasi aktivitas yang dilakukan oleh manusia, mesin dan peralatan dalam menghasilkan suatu produk atau layanan. Biaya bahan baku langsung dan biaya tenaga kerja langsung dibebankan langsung ke produk karena biaya ini adalah biaya langsung dari produk yang dapat dengan mudah dan akurat ditelusuri ke setiap produk. Sebaliknya, biaya overhead pabrik tidak dapat langsung dibebankan ke produk karena biaya ini adalah biaya pabrik tidak langsung.

Menurut Mulyadi (2007), kumpulan biaya aktivitas adalah akun yang digunakan untuk menggabungkan dua atau lebih aktivitas yang memiliki pendorong aktivitas yang sama untuk secara bersama-sama dibebankan ke produk / layanan menggunakan hanya satu pendorong aktivitas. Sedangkan kurs driver aktivitas adalah kurs yang digunakan untuk membebankan biaya aktivitas ke

* Corresponding author's e-mail: meliza@pcr.ac.id

http://openjournal.unpam.ac.id/index.php/JABI 
Jurnal Akuntansi Berkelanjutan Indonesia - Vol. 3, No. 2, Mei 2020 - Zifi; Renaldo \& Salsabilah

aktivitas lain atau ke produk / layanan. Tingkat driver Aktivitas dihitung menggunakan rumus:

Kumpulan biaya digunakan sebagai penapisan biaya overhead pabrik. Kumpulan biaya filter (kumpulan) dibagi menjadi tiga, yaitu:

1. Cost pool-Pabrik Perhitungan cost pool - pabrik adalah saringan yang paling kasar, sehingga perhitungan biaya dengan saringan ini sangat tidak akurat, terutama jika perusahaan menghasilkan beberapa macam produk yang berbeda.

2. Cost pool - Departemen Produksi Keakuratan perhitungan harga pokok produk akan meningkat jika saringan yang digunakan adalah cost pool - departemen produksi. Hal ini disebabkan saringan biayanya lebih halus daripada cost pool - pabrik. Masing-masing departemen produksi memilik karakteristik proses yang berbeda yang mengakibatkan driver biaya yang digunakan juga harus berbeda untuk setiap departemen sesuai dengan karakteristik proses produksi di departemen tersebut.

3. Cost pool - Aktivitas Saringan biaya dengan menggunakan cost pool ini sangat halus sehingga perhitungan biayanya sangat terperinci dan akurat. Selain itu, juga memudahkan manajemen dalam meningkatkan efisiensi biaya dengan mengelola aktivitas operasional yang tidak bernilai tambah.

\section{METODE RISET}

Metode penelitian ini adalah kuantitatif dengan desain penelitian studi kasus (Case Study Design) yaitu penelitian mendalam tentang masalah penelitian tertentu. Objek dalam penelitian ini adalah salah satu rumah sakit swasta di Jambi. Teknik pengumpulan data dalam penelitian ini menggunakan metode wawancara dan dokumentasi. Data penelitian ini menggunakan data tahun 2018 dan perhitungan tarif berdasarkan metode Activity Based Costing. Sumber data penelitian terdiri dari data primer dan data sekunder. Data primer yang digunakan adalah data yang diperoleh secara langsung dari Rumah Sakit Jambi berupa wawancara, tarif keuangan, data jumlah pasien, dan data biaya-biaya yang berkaitan dengan rawat inap. Sedangkan data sekunder diperoleh dari buku akuntansi biaya dan jurnal terkait dengan metode penentuan tarif rawat inap untuk rumah sakit, surat keputusan menteri kesehatan, dan data lainnya yang berkaitan.

Teknik analisis data dalam penelitian ini sebagai berikut:

1. Mengumpulkan data-data yang dibutuhkan dari rumah sakit lalu mengidentifikasikan aktivitas-aktivitas yang berkaitan dengan rawat inap rumah sakit.

2. Mengklasifikasikan aktivitas biaya ke dalam berbagai aktivitas, pada langkah ini biaya digolongkan kedalam aktivitas yang terdiri dari 4 kategori: unit level activities, batch level activities, product sustaining activities, facility sustaining activities dengan cara mengidentifikasi aktivitas- aktivitas tersebut.

* Corresponding author's e-mail: meliza@pcr.ac.id

http://openjournal.unpam.ac.id/index.php/JABI 
Jurnal Akuntansi Berkelanjutan Indonesia - Vol. 3, No. 2, Mei 2020 - Zifi; Renaldo \& Salsabilah

3. Mengidentifikasikan cost driver yang dimaksudkan untuk memudahkan dalam penentuan tarif/unit cost driver. Setelah aktivitas-aktivitas diidentifikasi sesuai dengan level aktivitasnya, langkah selanjutnya adalah mengidentifikasi cost driver dari setiap biaya aktivitas. Pengidentifikasian yang dimaksudkan dalam penentuan kelompok aktivitas adalah tarif atau unit cost driver.

4. Menentukan tarif/unit cost driver yang artinya biaya per unit cost driver yang dihitung untuk suatu aktivitas.

5. Membebankan biaya ke produk dengan menggunakan tarif cost driver dan ukuran aktivitas.

a. Pembebanan biaya overhead dari tiap aktivitas ke setiap kamar.

b. Kemudian perhitungan tarif masing-masing tipe kamar dengan metode activity based costing.

6. Membandingkan tarif jasa rawat inap RS berdasarkan metode traditional costing dengan metode activity based costing.

\section{ANALISIS DATA DAN PEMBAHASAN}

Tarif Jasa Rawat Inap berdasarkan Activity Based Costing

1. Identifikasi Data

Mengidentifikasi kegiatan yang terkait dengan rawat inap rumah sakit seperti terlihat pada tabel 1 berikut.

\section{Tabel 1. Identifikasi level Aktivitas}

\begin{tabular}{lll}
\hline No & Aktivitas & Level Aktivitas \\
\hline 1 & $\begin{array}{l}\text { Aktivitas Pelayanan Administrasi } \\
\text { Umum }\end{array}$ & Batch Level \\
2 & $\begin{array}{l}\text { Aktivitas pelayanan perawatan } \\
\text { pasien }\end{array}$ & Unit Level \\
3 & Aktivitas Visite Dokter & Unit Level \\
4 & Aktivitas Penginapan Pasien & Unit Level \\
5 & $\begin{array}{l}\text { Aktivitas Pelayanan Pencucian } \\
\text { atau Laundry }\end{array}$ & Unit Level \\
6 & $\begin{array}{l}\text { Aktivitas Pelayanan Pembersihan } \\
\text { Kamar atau Cleaning Service }\end{array}$ & Batch Level \\
7 & $\begin{array}{l}\text { Aktivitas Pelayanan Penyediaan } \\
\text { Konsumsi }\end{array}$ & Unit Level \\
9 & Aktivitas Penggunaan Energi & Unit Level \\
9 & Aktivitas Pemeliharaan Bangunan & Facility Level \\
\hline
\end{tabular}

* Corresponding author's e-mail: meliza@pcr.ac.id

http://openjournal.unpam.ac.id/index.php/JABI 
Jurnal Akuntansi Berkelanjutan Indonesia - Vol. 3, No. 2, Mei 2020 - Zifi; Renaldo \& Salsabilah

\section{Identifikasi Cost drivers}

a. Aktivitas Pelayanan Administrasi Umum Aktivitas pelayanan administrasi umum dilakukan ketika pasien tersebut dinyatakan perlu untuk dirawat inap serta menginput data pasien ke database baik yang baru masuk atau pindah kamar. Sumber daya yang akan dikonsumsi secara umum merupakan biaya gaji pegawai administrasi, biaya penyusutan peralatan, dan biaya alat tulis kantor. Adapun cost driver dari aktivitas ini dapat diidentifikasikan dari jumlah pasien rawat inap. Karena biaya pendataan ini meningkat seiring dengan jumlah orang yang rawat inap. Semakin banyak pasien untuk didata maka biaya untuk pendataan semakin meningkat.

b. Aktivitas Pelayanan Perawatan Pasien

Sumber daya yang akan dikonsumsi secara umum merupakan biaya gaji perawat. Aktivitas ini memiliki pemicu biaya yaitu jumlah hari rawat. Asumsi yang mendasari adalah semakin banyak hari rawat, maka semakin tinggi pula tingkat kebutuhan perawat yang melayani pasien pada kamar tersebut.

c. Aktivitas Visite Dokter

Aktivitas visite dokter ini adalah kunjungan dokter untuk mengontrol perkembangan kesehatan pasien setiap hari. Sumber daya yang akan dikonsumsi secara umum merupakan biaya gaji dokter. Biaya visite dokter merupakan biaya langsung.

d. Aktivitas Penginapan Pasien

Aktivitas penginapan yang dapat dipilih oleh pasien terdiri dari beberapa kelas dengan fasilitas-fasilitas yang berbeda. Perbedaan fasilitas menyebabkan konsumsi biaya yang berbeda sehingga untuk mengetahui total biaya dari aktivitas penginapan pasien masing-masing kelas harus dihitung secara terpisah. Aktivitas ini memiliki pemicu biaya yaitu jumlah hari rawat inap.

e. Aktivitas Pelayanan Pencucian atau Laundry

Aktivitas pelayanan pencucian atau laundry merupakan aktivitas pelayanan rumah sakit kepada pasien berupa pelayanan pencucian seprei, selimut, dan sarung bantal. Sumber daya yang akan dikonsumsi secara umum merupakan biaya gaji, biaya perlengkapan laundry, dan penyusutan inventaris. Adapun cost driver dari aktivitas ini dapat diidentifikasikan dari seluruh jumlah hari rawat inap.

f. Aktivitas Pelayanan Pembersihan Kamar

Aktivitas pelayanan pembersihan atau cleaning service adalah aktivitas pelayanan rumah sakit kepada pasien dengan membersihkan ruangan meliputi tempat sampah, lantai ruangan dan toilet. Sumber daya yang akan dikonsumsi secara umum merupakan biaya gaji dan biaya perlengkapan. Adapun cost driver dari aktivitas ini dapat diidentifikasikan dari luas ruangan.

g. Aktivitas Pelayanan Penyediaan Konsumsi

* Corresponding author's e-mail: meliza@pcr.ac.id

http://openjournal.unpam.ac.id/index.php/JABI 
Jurnal Akuntansi Berkelanjutan Indonesia - Vol. 3, No. 2, Mei 2020 - Zifi; Renaldo \& Salsabilah

Aktivitas pelayanan penyediaan konsumsi adalah aktivitas pembuatan dan pembagian makanan pada pasien setiap hari. Sumber daya yang akan dikonsumsi secara umum merupakan biaya gaji, dan biaya bahan makanan. Adapun cost driver dari aktivitas ini dapat diidentifikasikan dari jumlah hari rawat inap.

h. Aktivitas Penggunaan Energi

Aktivitas penggunaan energi adalah aktivitas yang sangat dibutuhkan oleh setiap instansi. Rumah sakit memerlukan tenaga listrik untuk keberlangsungan aktivitas rumah sakit seperti menunjang aktivitas tindakan persalinan. Adapun cost driver dari aktivitas ini dapat diidentifikasi dari kwh yang terpakai.

i. Aktivitas Pemeliharaan Bangunan. Aktivitas pemeliharaan bangunan merupakan aktivitas memelihara bangunan agar kondisinya tetap terjaga dan dapat digunakan dengan baik. Sumber biaya yang dikonsumsi secara umum merupakan biaya penyusutan bangunan, biaya pemeliharaan, biaya gaji teknisi, biaya penyusutan genset dan pompa air, biaya bahan bakar genset. Adapun cost driver dari aktivitas ini dapat diidentifikasikan dari total luas kamar.

3. Menghitung Harga Pokok Kamar Rawat Inap

Setelah menentukan cost driver, selanjutnya menghitung harga pokok kamar rawat inap untuk masing-masing jenis kamar. Adapun langkah- langkah dalam melakukan perhitungan harga pokok adalah sebagai berikut:

a. Menghitung biaya overhead yang dibebankan pada masing-masing tipe kamar dengan cara mengkali tarif per unit cost driver dengan driver yang digunakan oleh masing-masing jenis kamar rawat inap.

b. Menjumlahkan seluruh biaya aktivitas yang telah dikelompokkan.

c. Membagi total biaya aktivitas dengan jumlah hari rawat inap pada masing-masing jenis kamar rawat inap. Untuk menghitung harga pokok masing-masing kelas kamar rawat inap dapat dilihat pada tabel di bawah ini:

Tabel 2. Perhitungan Harga Pokok Rawat Inap VIP

Metode Activity Based Costing

\begin{tabular}{|l|c|c|c|}
\hline \multicolumn{1}{|c|}{ Aktivitas } & $\begin{array}{c}\text { Tarif Per Unit Cost } \\
\text { Driver (Rp) }\end{array}$ & Driver & Jumlah (Rp) \\
\hline $\begin{array}{l}\text { Aktivitas Administrasi } \\
\text { dan Umum }\end{array}$ & $85,060.51$ & 512 & $43,550,981.35$ \\
\hline $\begin{array}{l}\text { Aktivitas Pelayanan } \\
\text { Perawatan Pasien }\end{array}$ & $60,656.43$ & 1,374 & $83,341,937.10$ \\
\hline $\begin{array}{l}\text { Aktivitas Penginapan } \\
\text { pasien }\end{array}$ & $8,501.63$ & 1,374 & $11,681,240.96$ \\
\hline $\begin{array}{l}\text { Aktivitas Pelayanan } \\
\text { Pencucian/ Laundry }\end{array}$ & $262,629.54$ & 322.54 & $84,708,532.15$ \\
\hline Aktivitas Pelayanan & & &
\end{tabular}

* Corresponding author's e-mail: meliza@pcr.ac.id

http://openjournal.unpam.ac.id/index.php/JABI 
Jurnal Akuntansi Berkelanjutan Indonesia - Vol. 3, No. 2, Mei 2020 - Zifi; Renaldo \& Salsabilah

\begin{tabular}{|l|c|c|c|}
\hline Pembersihan Kamar & & \\
\hline $\begin{array}{l}\text { Aktivitas Penyediaan } \\
\text { Konsumsi }\end{array}$ & $41,486.66$ & 1,374 & $57,002,664.41$ \\
\hline $\begin{array}{l}\text { Aktivitas Penggunaan } \\
\text { Energi }\end{array}$ & $4,747.49$ & 19,654 & $93,307,140.74$ \\
\hline $\begin{array}{l}\text { Aktivitas Pemeliharaan } \\
\text { Bangunan }\end{array}$ & $176,495.46$ & 322.54 & $56,926,845.75$ \\
\hline \multicolumn{2}{|l|}{ Total biaya aktivitas dibebankan ke VIP } & $465,369,670.46$ \\
\hline Lama hari pemakaian & 1,374 days \\
\hline Biaya Aktivitas per kamar rawat inap & 338,697 \\
\hline Biaya Langsung per kamar & $\mathbf{5 5 8 , 6 9 7}$ \\
\hline Harga Pokok Rawat Inap VIP & & 220,000 \\
\hline
\end{tabular}

Sumber: Data diolah

Berdasarkan tabel 2 dapat dilihat bahwa harga pokok rawat inap untuk kamar tipe VIP dengan menggunakan metode activity based costing adalah sebesar Rp 558.697 untuk tahun 2018.

Tabel 3. Perhitungan Harga Pokok Rawat Inap Kelas I Metode Activity Based Costing

\begin{tabular}{|c|c|c|c|}
\hline Aktivitas & $\begin{array}{l}\text { Tarif Per Unit Cost } \\
\text { Driver (Rp) }\end{array}$ & Driver & Jumlah (Rp) \\
\hline $\begin{array}{l}\text { Aktivitas Administrasi } \\
\text { dan Umum }\end{array}$ & $85,060.51$ & 1,064 & $90,504,383.13$ \\
\hline $\begin{array}{l}\text { Aktivitas Pelayanan } \\
\text { Perawatan Pasien }\end{array}$ & $60,656.43$ & 3,966 & $240,563,407.96$ \\
\hline AktivStambiert Doktekliolah & & & $19,746,120.00$ \\
\hline $\begin{array}{l}\text { Aktivitas Penginapan } \\
\text { pasien }\end{array}$ & $8,501.63$ & 3,966 & $33,717,468.46$ \\
\hline $\begin{array}{l}\text { Aktivitas Pelayanan } \\
\text { Pencucian/ Laundry }\end{array}$ & $262,629.54$ & 220 & $28,889,249.51$ \\
\hline $\begin{array}{l}\text { Aktivitas Pelayanan } \\
\text { Pembersihan Kamar }\end{array}$ & $41,486.66$ & 3,966 & $164,536,075.00$ \\
\hline $\begin{array}{l}\text { Aktivitas Penyediaan } \\
\text { Konsumsi }\end{array}$ & $4,747.49$ & 24,187 & $114,827,506.51$ \\
\hline $\begin{array}{l}\text { Aktivitas Penggunaan } \\
\text { Energi }\end{array}$ & $176,495.46$ & 220 & $19,414,500.63$ \\
\hline $\begin{array}{l}\text { Aktivitas Pemeliharaan } \\
\text { Bangunan }\end{array}$ & $85,060.51$ & 1,064 & $90,504,383.13$ \\
\hline \multicolumn{3}{|c|}{ Total biaya aktivitas dibebankan ke Kelas I } & $712,198,711.19$ \\
\hline \multicolumn{3}{|c|}{ Lama hari pemakaian } & 3,966 days \\
\hline \multicolumn{3}{|c|}{ Biaya Aktivitas per kamar rawat inap } & 179,576 \\
\hline \multicolumn{3}{|c|}{ Biaya Langsung per kamar } & 180,000 \\
\hline \multicolumn{3}{|c|}{ Harga Pokok Rawat Inap Kelas I } & 359,576 \\
\hline
\end{tabular}

Berdasarkan tabel 3 dapat dilihat bahwa harga pokok rawat inap untuk kamar tipe kelas I dengan menggunakan metode activity based costing 
Jurnal Akuntansi Berkelanjutan Indonesia - Vol. 3, No. 2, Mei 2020 - Zifi; Renaldo \& Salsabilah

adalah Rp 359.576 untuk tahun 2018.

Tabel 4. Perhitungan Harga Pokok Rawat Inap Kelas II Metode Activity Based Costing

\begin{tabular}{|l|c|c|c|}
\hline \multicolumn{1}{|c|}{ Aktivitas } & $\begin{array}{c}\text { Tarif Per Unit Cost } \\
\text { Driver (Rp) }\end{array}$ & Driver & Jumlah (Rp) \\
\hline $\begin{array}{l}\text { Aktivitas Administrasi } \\
\text { dan Umum }\end{array}$ & $85,060.51$ & 741 & $63,029,838.25$ \\
\hline $\begin{array}{l}\text { Aktivitas Pelayanan } \\
\text { Perawatan Pasien }\end{array}$ & $60,656.43$ & 2,792 & $169,352,757.19$ \\
\hline Aktivitas Visit Dokter & & & $15,228,921.67$ \\
\hline $\begin{array}{l}\text { Aktivitas Penginapan } \\
\text { pasien }\end{array}$ & $8,501.63$ & 2,792 & $23,736,535.69$ \\
\hline $\begin{array}{l}\text { Aktivitas Pelayanan } \\
\text { Pencucian/ Laundry }\end{array}$ & $262,630.90$ & 210.67 & $18,442,817.15$ \\
\hline $\begin{array}{l}\text { Aktivitas Pelayanan } \\
\text { Pembersihan Kamar }\end{array}$ & $41,486.66$ & 2,792 & $115,830,741.65$ \\
\hline $\begin{array}{l}\text { Aktivitas Penyediaan } \\
\text { Konsumsi }\end{array}$ & $4,747.49$ & 6,671 & $31,670,496.38$ \\
\hline $\begin{array}{l}\text { Aktivitas Penggunaan } \\
\text { Energi }\end{array}$ & $176,495.46$ & 210.67 & $12,394,099.54$ \\
\hline $\begin{array}{l}\text { Aktivitas Pemeliharaan } \\
\text { Bangunan }\end{array}$ & $85,060.51$ & 741 & $63,029,838.25$ \\
\hline \multicolumn{2}{|l|}{ Total biaya aktivitas dibebankan ke Kelas II } & $449,686,225.52$ \\
\hline Lama hari pemakaian & & 2,792 days \\
\hline Biaya Aktivitas per kamar rawat inap & 161,062 \\
\hline Biaya Langsung per kamar & $\mathbf{3 1 1 , 0 6 2}$ \\
\hline Harga Pokok Rawat Inap Kelas II \\
\hline
\end{tabular}

Sumber: Data diolah

Berdasarkan tabel 4 dapat dilihat bahwa aktivitas penginapan pasien, kegiatan pelayanan pembersihan kamar dan kegiatan pemeliharaan gedung merupakan kegiatan bersama sehingga biaya kegiatan total kegiatan dibagi 3 karena di ruang Kelas II terdapat 3 pasien. Jadi biaya untuk kamar Kelas II menggunakan biaya berdasarkan aktivitas adalah Rp 311.062 untuk 2018.

Tabel 5. Perhitungan Harga Pokok Rawat Inap Kelas III Metode Activity Based Costing

\begin{tabular}{|l|c|c|c|}
\hline \multicolumn{1}{|c|}{ Aktivitas } & $\begin{array}{c}\text { Tarif Per Unit Cost } \\
\text { Driver (Rp) }\end{array}$ & Driver & Jumlah (Rp) \\
\hline $\begin{array}{l}\text { Aktivitas Administrasi } \\
\text { dan Umum }\end{array}$ & $85,060.51$ & 982 & $83,529,421.27$ \\
\hline $\begin{array}{l}\text { Aktivitas Pelayanan } \\
\text { Perawatan Pasien }\end{array}$ & $60,656.43$ & 3,618 & $219,454,969.74$ \\
\hline
\end{tabular}

* Corresponding author's e-mail: meliza@pcr.ac.id http://openjournal.unpam.ac.id/index.php/JABI 
Jurnal Akuntansi Berkelanjutan Indonesia - Vol. 3, No. 2, Mei 2020 - Zifi; Renaldo \& Salsabilah

\begin{tabular}{|l|c|c|c|}
\hline Aktivitas Visit Dokter & & & $17,046,010.00$ \\
\hline $\begin{array}{l}\text { Aktivitas Penginapan } \\
\text { pasien }\end{array}$ & $8,501.63$ & 3,618 & $30,758,900.88$ \\
\hline $\begin{array}{l}\text { Aktivitas Pelayanan } \\
\text { Pencucian/ Laundry }\end{array}$ & $262,630.90$ & 258.74 & $16,988,279.69$ \\
\hline $\begin{array}{l}\text { Aktivitas Pelayanan } \\
\text { Pembersihan Kamar }\end{array}$ & $41,486.66$ & 3,618 & $150,098,718.94$ \\
\hline $\begin{array}{l}\text { Aktivitas Penyediaan } \\
\text { Kgnsumsi }\end{array}$ & $4,747.49$ & 7,592 & $36,042,933.37$ \\
\hline $\begin{array}{l}\text { UAktivitas Penggunaan } \\
\text { Ifnergi } \\
\text { b }\end{array}$ & $176,495.46$ & 258.74 & $11,416,608.85$ \\
$\begin{array}{l}\text { Aktivitas Pemeliharaan } \\
\text { Bangunan }\end{array}$ & $85,060.51$ & 982 & $83,529,421.27$ \\
\hline \begin{tabular}{l} 
Total biaya aktivitas dibebankan ke Kelas III \\
\hline Lama hari pemakaian
\end{tabular} & $565,335,842.74$ \\
\hline Biaya Aktivitas per kamar rawat inap & 3,618 days \\
\hline \multicolumn{2}{|l|}{ Biaya Langsung per kamar } & 156,256 \\
\hline Harga Pokok Rawat Inap Kelas III & $\mathbf{2 7 6 , 2 5 6}$ \\
\hline
\end{tabular}

Berdasarkan tabel 5 dapat dilihat bahwa aktivitas penginapan pasien, kegiatan pelayanan pembersihan kamar dan kegiatan pemeliharaan gedung merupakan kegiatan bersama sehingga biaya kegiatan total kegiatan dibagi 4 karena di ruang Kelas III terdapat 4 pasien. Jadi biaya untuk kamar Kelas III menggunakan biaya berdasarkan aktivitas adalah Rp 276.256 untuk 2018.

4. PerhitunganTarif Rawat Inap Berdasarkan Activity Based Costing

Berdasarkan perhitungan harga pokok rawat inap diatas, maka selanjutnya melakukan perhitungan tarif berdasarkan metode activity based costing dengan asumsi laba yang diharapkan oleh rumah sakit adalah $20 \%$.

Tabel 6. Perhitungan Tarif Rawat Inap Berdasarkan Metode Activity Based Costing

\begin{tabular}{clll}
\hline $\begin{array}{c}\text { Tipe } \\
\text { Kamar }\end{array}$ & $\begin{array}{c}\text { Harga Pokok Activity } \\
\text { Based Costing (Rp) }\end{array}$ & $\begin{array}{l}\text { Laba yang } \\
\text { diharapkan } \\
(\%)\end{array}$ & $\begin{array}{l}\text { Tarif Activity } \\
\text { Based Costing (Rp) }\end{array}$ \\
\hline VIP & 558,697 & 20 & 670,436 \\
Kelas I & 359,576 & 20 & 431,491 \\
Kelas II & 311,062 & 20 & 373,275 \\
Kelas III & 276,256 & 20 & 331,508 \\
\hline
\end{tabular}

Sumber: Data diolah

5. Perbandingan Tarif Jasa Rawat Inap Metode Activity Based Costing dengan Traditional Costing. 
Jurnal Akuntansi Berkelanjutan Indonesia - Vol. 3, No. 2, Mei 2020 - Zifi; Renaldo \& Salsabilah

Tabel 7. Perbandingan Tarif Jasa rawat Inap Metode Activity Based Costing dengan Traditional Costing

\begin{tabular}{cclll}
\hline $\begin{array}{c}\text { Tipe } \\
\text { Kamar }\end{array}$ & $\begin{array}{c}\text { Tarif } \\
\text { Metode } \\
\text { ABC } \\
(\mathbf{R p )}\end{array}$ & $\begin{array}{l}\text { Tarif } \\
\text { Traditional } \\
\text { Costing } \\
(\mathbf{R p})\end{array}$ & Selisih & Hasil Perbandingan \\
\hline VIP & 670,436 & 850,000 & 179,564 & Lebih Murah \\
Kelas I & 431,491 & 550,000 & 118,509 & Lebih Murah \\
Kelas II & 373,275 & 375,000 & 1,725 & Lebih Murah \\
Kelas III & 331,508 & 275,000 & $(56,508)$ & Lebih Mahal \\
\hline
\end{tabular}

Sumber: Data diolah

Berdasarkan perhitungan di atas, dapat diketahui bahwa hasil perhitungan tarif layanan rawat inap menggunakan metode activity based costing untuk kamar tipe kamar VIP sebesar Rp 670.436, kamar Kelas I Rp 431.491, kamar Kelas II Rp 373.275 dan kamar Kelas III dari Rp 331.508. Jika dibandingkan dengan tarif yang digunakan oleh XXX Hospital, penetapan biaya berdasarkan aktivitas memberikan hasil yang lebih murah untuk kamar VIP, Kelas I, dan Kelas II. Sedangkan kamar Kelas III memberikan hasil lebih mahal. Dengan selisih untuk kelas III sebesar Rp. 56.508. Sedangkan untuk kelas VIP, kelas I, dan kelas II metode $\mathrm{ABC}$ memberikan hasil yang lebih murah, dengan perbedaan untuk kelas VIP sebesar Rp 179.564, untuk kelas I Rp 118.509 dan untuk kelas II Rp 1.725.

\section{KESIMPULAN DAN SARAN}

Berdasarkan uraian pembahasan, maka dapat disimpulkan bahwa perhitungan tarif rawat inap dengan menggunakan metode activity based costing yaitu untuk tipe kamar VIP sebesar Rp 670.436, tipe kamar kelas I sebesar Rp 431.491, tipe kamar kelas II sebesar Rp 373.275, dan tipe kamar kelas III sebesar Rp 331.508. Dari hasil perhitungan tersebut, maka terdapat perbedaan penetapan tarif rawat inap dengan traditional costing atau perhitungan perusahaan yaitu selisih untuk tipe kelas VIP lebih murah sebesar Rp 179.564, tipe kelas I lebih murah sebesar Rp 118.509, tipe kelas II lebih murah sebesar Rp 1.725, dan tipe kelas III lebih mahal Rp 56.508.

Saran yang dapat digunakan sebagai bahan pertimbangan pengambilan kebijakan rumah sakit adalah jika ingin mendapatkan laba sesuai dengan target perusahaan sebesar 20\% untuk kamar kelas III, maka rumah sakit seharusnya menaikkan tarif jasa rawat inap dengan menggunakan activity based costing dengan harga sebesar Rp 331,508. Jika rumah sakit tidak ingin menaikkan tarif jasa rawat inapnya, maka bisa mengurangi target laba yang diinginkan untuk kamar Kelas III.

* Corresponding author's e-mail: meliza@pcr.ac.id

http://openjournal.unpam.ac.id/index.php/JABI 
Jurnal Akuntansi Berkelanjutan Indonesia - Vol. 3, No. 2, Mei 2020 - Zifi; Renaldo \& Salsabilah

\section{DAFTAR PUSTAKA}

Aini, N., \& Dwi, F. (2012). Penerapan Metode Activity Based Costing System Dalam Menentukan Besarnya Tarif Jasa Rawat Inap Pada Rumah Sakit Mata di Surabaya. Jurnal Ekonomi Vol .12.

Fadilah, S. (2009). Activity Based Costing (ABC) Sebagai Pendekatan Baru Untuk Menghitung Analisis Standar Belanja (ASB) Dalam Penyusunan Anggaran Pendapatan Belanja Daerah (APBD). Jurnal Telaah dan Riset Akuntansi , 2.

Hansen, D. R., \& Mowen, M. M. (2012). Akuntansi Manajemen (Edisi kedelapan ed., Vol. 1). Jakarta: Salemba Empat.

Maghfira, F., \& Basri, H. (2016). Penerapan Metode Activity Based Costing Dalam Penetapan Tarif Jasa Rawat Inap pada Rumah Sakit Cut Meutia Langsa. Jurnal Ilmiah Mahasiswa Ekonomi Akuntansi (JIMEKA) , 1, 4759.

Mulyadi. (2007). Activity Based Cost System: Sistem Informasi Biaya Untuk Pengurangan Biaya (Edisi Keenam ed.). Yogyakarta: UPP AMP YKPN.

Nailufar, U., \& dkk. (2015). Penerapan Activity Based Costing System Dalam Menentukan Harga Pokok Jasa Rawat Inap (Studi pada RSUD Ibnu Sina Kabupaten Gresik. Jurnal Administrasi Bisnis (JAB), 24.

Pelo, G. H. (2012). Penerapan Activity Based Costing Pada Tarif Jasa Rawat Inap RSUD Daya di Makassar. Skripsi, Universitas Hasanuddin, Program Studi Akuntansi, Makassar.

Rikardo, R. (2016). Penerapan Activity Based Costing Pada Tarif Jasa Rawat Inap. Skripsi, Universitas Lampung, Program Studi Akuntansi, Bandarlampung. 